\title{
Laicy jako rzecznicy. Opinie osób niepełnosprawnych jako głos w polemice toczonej przez reprezentantów socjologii medycyny i studiów nad niepełnosprawnością
}

\author{
Tomasz Masłyk \\ AGH, Akademia Górniczo-Hutnicza w Krakowie
}

DOI: http://dx.doi.org/10.18778/1733-8069.16.3.06

\section{Słowa kluczowe: socjologia medycyny, studia nad niepełnosprawnością, niepełnosprawność, badania jakościowe}

\begin{abstract}
Abstrakt: W drugiej połowie dwudziestego wieku tematyka niepełnosprawności stała się przedmiotem debat akademickich i badań empirycznych prowadzonych na gruncie nauk społecznych w ramach dwóch równolegle rozwijających się nurtów. W pierwszym z nich - socjologii medycyny (medical sociology), uwagę koncentrowano na naturze i przyczynach chorób przewlekłych i niepełnosprawności, stawiając w centrum zainteresowania szeroko rozumiane dysfunkcje zdrowotne, interpretowane najczęściej w ujęciu indywidualnym. W drugim nurcie - studiach nad niepełnosprawnością (disability studies), uwaga badaczy skupiała się przede wszystkim na problemach społecznych (model społeczny) jako źródle niepełnosprawności oraz na adekwatnych im środkach zaradczych. W modelu społecznym niepełnosprawność traktowano przede wszystkim jako pochodną szeroko rozumianych ograniczeń zewnętrznych, a nie jako konsekwencję dysfunkcji na poziomie organizmu.

Celem artykułu jest przybliżenie założeń teoretycznych tych dwóch nurtów z jednoczesnym uwzględnieniem opinii osób niepełnosprawnych, jako głosu uzupełniającego argumentację w toczonej dyskusji. Opinie na temat istoty własnej niepełnosprawności, jej źródeł i konsekwencji wyrażone zostały przez 45 osób niepełnosprawnych, które wzięły udział w badaniach terenowych zrealizowanych z wykorzystaniem techniki indywidualnych wywiadów pogłębionych. Uczestnicy badania na ogół interpretowali swoją niepełnosprawność i jej przyczyny w perspektywie medycznej (indywidualistycznej). Samą dysfunkcję traktowali jako fundamentalną dla budowania statusu centralnego, w mniejszym stopniu przypisując przyczyny swojej niepełnoprawności uwarunkowaniom społecznym.
\end{abstract}

Tomasz Masłyk, socjolog, doktor habilitowany nauk społecznych w dyscyplinie socjologia, adiunkt na Wydziale Humanistycznym AGH. Autor publikacji z zakresu socjologii polityki, socjologii Internetu i nowych mediów oraz socjologii niepełnosprawności.

\author{
Adres kontaktowy: \\ Wydział Humanistyczny AGH \\ ul. Gramatyka 8a/106a \\ 30-071 Kraków \\ e-mail: tomaslyk@agh.edu.pl
}




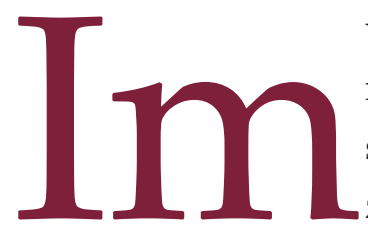

więcej wiemy o przyczynach i naturze niepełnosprawności, tym trudniej o jej jednoznaczną, definicyjną wykładnię. Niepełnosprawność jest niewiadomą, której doświadczamy, ale niekoniecznie ją rozumiemy (Albrecht, Seelman, Bury 2001: 1). Paradoksalnie, odejście od prostych i potocznych interpretacji właściwych dla wieków minionych - dewiacji jako grzechu, przyczyny przestępstw czy choroby (Conrad, Schneider 1992: 27-28) i wprowadzenie problematyki niepełnosprawności do dyskursu naukowego, skutkowało mnogością i sprzecznością jej interpretacji. Wiązało się to z próbą zrozumienia zależności pomiędzy schorzeniem (disease), chorobą (illness) czy niepełnosprawnością. Rezultaty tych zabiegów prowadziły do rozdźwięku pomiędzy instrumentami zaprojektowanymi do opisu i diagnozy choroby lub niepełnosprawności a możliwością ich operacjonalizacji i wykorzystania $\mathrm{w}$ badaniach. W rezultacie doszło do ukształtowania się rozbieżnych stanowisk pomiędzy pracownikami służby zdrowia, domagającymi się jednoznacznych kategorii diagnostycznych, potrzebnych do klasyfikowania chorób i schorzeń, oraz badaczami służby zdrowia, demografami, epidemiologami zdrowia publicznego, którzy starali się zrozumieć szerszy kontekst powiązań pomiędzy schorzeniem a niepełnosprawnością (Albrecht 2010: 193).

Sytuacji nie ułatwiał fakt, że główny akcent w badaniach dotyczących zdrowia i choroby przesunięty został w kierunku „,społecznych determinant zdrowia", takich jak praktyki i warunki życia społecznego (styl życia, poziom życia i charakter pracy), pozycja klasowa (dochód, wykształcenie i zawód), sytuacje stresowe, ubóstwo i warunki gospodarcze (bezrobocie, recesja), czynniki polityczne (polityka, świadczenia społeczne) i czynniki religijne. Wszyst- kie one tworzyły złożony zbiór elementów, które w zależności od kontekstu i wzajemnych powiązań mogły wywierać pozytywny lub negatywny wpływ na zdrowie jednostek, grup i społeczności. Uwarunkowania społeczne z jednej strony sprzyjały chorobie i niepełnosprawności, ale $z$ drugiej zwiększały szanse na jej zapobieganie lub radzenie sobie z nią (Cockerham 2016: 4).

Chociaż dostępne dane jasno wskazują, że większość przewlekłych dolegliwości skutkuje powstaniem niepełnosprawności, to związek pomiędzy chorobą a niepełnosprawnością jest zagadnieniem złożonym (Gabe, Bury, Elston 2004: 79). Złożoność tę podkreślał w swojej w pływowej pracy Saad Z. Nagi (1965), wprowadzając rozróżnienie pomiędzy: 1. patologią (zakłócenie naturalnych procesów w organizmie, gdy próbuje on wrócić do normalnego stanu), 2. uszkodzeniem (anatomiczne lub fizjologiczne nieprawidłowości), 3. ograniczeniem funkcjonalnym (ograniczenie, które upośledza zdolność osoby do podejmowania codziennych aktywności i wykonywania ról społecznych) i 4. niepełnosprawnością (ekspresja ograniczeń funkcjonalnych w kontekście społecznym, będąca pochodną interakcji pomiędzy jednostką a środowiskiem, w którym są definiowane role społeczne). W tym duchu Phillip Wood przy wsparciu Michaela Bury'ego opracował Międzynarodową Klasyfikację Funkcjonowania, Niepełnosprawności i Zdrowia, która poszerzyła medyczny model choroby o zagadnienia psychospołeczne i społeczne (ICIDH 1980). Dalsze zmiany w tym kierunku wprowadzono 20 lat później w nowej wersji klasyfikacji ICF. Opisując niepełnosprawność, przesunięto w niej punkt ciężkości w kierunku kwestii społecznych: od klasyfikacji „skutków choroby” do klasyfikacji „składników zdrowia” z uwzględnieniem „czynników środowiskowych” i „czynników osobowych", które mogą odegrać istotną rolę w po- 
wstawaniu niepełnosprawności (ICIDH-2 2001). W tym nowym spojrzeniu niepełnosprawność traktowana była jako złożony konstrukt związany zarówno z funkcjami (czynnościami układów ciała przyp. TM) i strukturami ludzkiego ciała (budową anatomiczną - przyp. TM), jak i z codzienną, zadaniową aktywnością. Natomiast upośledzenie definiowano wyłącznie w odniesieniu do tych funkcji i struktur (Haveman 2006: 79).

W tym ujęciu istotnym pytaniem jest to, jaką rolę w kształtowaniu niepełnosprawności odgrywają owe funkcje i struktury, w jakim zaś - czynniki społeczne. Poszukiwanie odpowiedzi na to pytanie zaczęło wyznaczać oś sporu pomiędzy reprezentantami socjologii medycyny (medical sociology) i przedstawicielami studiów nad niepełnosprawnością (disability studies). Aktywność tych pierwszych koncentrowała się wokół paradygmatu dewiacji społecznych, natomiast drudzy rozwijali paradygmat społecznej opresji (Thomas 2010: 51). Socjologia medycyny była odpowiedzią na „dysfunkcjonalność medycyny, jej nieprzystosowanie do potrzeb zdrowotnych społeczeństwa" (Sokołowska 2009: 27), natomiast studia nad niepełnosprawnością były „teoretycznym ramieniem wspierającym ruchy społeczne na rzecz osób niepełnosprawnych" (Snyder 2006: 478 [tłum. własne]). Dla socjologów medycyny czynniki kontekstowe - społeczne, kulturowe, polityczne czy infrastrukturalne, pełnią rolę zmiennych pośredniczących $\mathrm{w}$ ciągu zależności wiążącym przyczynę (etiologia) z upośledzeniem (patologia) i manifestacją (niepełnosprawność). Przedstawiciele studiów nad niepełnosprawnością podważają istnienie bezpośredniego związku pomiędzy upośledzeniem a niepełnosprawnością, wskazując, że ta ostatnia warunkowana jest przede wszystkim wpływem czynników społecznych, a nie dysfunkcjami na poziomie organizmu.
Porównanie genezy oraz ogólnych założeń rozwijanych w obrębie socjologii medycyny i studiów nad niepełnosprawnością jest jednym z celów artykułu. Zabieg ten pozwolił zarysować kontekst teoretyczny, a tym samym stworzyć punkt odniesienia dla realizacji celu nadrzędnego. Celem tym było przedstawienie opinii osób niepełnosprawnych, z założenia niezaangażowanych laików, na temat tego, jak rozumieją swoją niepełnoprawność, jakie czynniki ją wywołują i co warunkuje proces wychodzenia z niepełnoprawności. Przyjęto, że wiedza laików rozumiana jako idee i perspektywy, które wykorzystywane są do interpretowania własnych doświadczeń związanych z chorobą i niepełnosprawnością w życiu codziennym (Gabe, Bury, Elston 2004: 135), może stanowić ważny głos w toczonej dyskusji. Opierając się na ich opiniach, podjęto również próbę odpowiedzi na pytanie, czy rozumienie własnej niepełnosprawności przez osoby niepełnoprawne jest bliższe stanowisku indywidualnemu (medycznemu), czy społecznemu. Inaczej pisząc, czy osoby niepełnosprawne mogłyby pełnić rolę niezaangażowanych rzeczników którejś ze stron prowadzonej polemiki. Interpretacji dokonano w oparciu o materiał empiryczny uzyskany $\mathrm{w}$ trakcie indywidualnych wywiadów pogłębionych z osobami niepełnoprawnymi różniącymi się stopniem i rodzajem niepełnoprawności.

\section{Różnica perspektyw - socjologia medycyny i studia nad niepełnosprawnością}

Socjologia medycyny (medical sociology) wywodzi się z trzech przenikających się koncepcji: medycyny jako nauki społecznej (medicine as a social science), medycyny społecznej (social medicine) i socjologii jako nauki o medycynie (sociology of medicine). Wszystkie trzy koncentrowały się na wyjaśnieniu związku po- 
między uwarunkowaniami społecznymi a problemami zdrowotnymi przy założeniu, że choroba jest zawsze w sposób pośredni zależna i warunkowana przez działania społeczne i środowisko kulturowe (Bloom 2002: 11).

Z czasem rozwój socjologii medycyny zaczął postępować w dwóch nurtach, które Robert Strauss (1957: 203) określił jako socjologię o medycynie (sociology of medicine) i socjologie w medycynie (sociology in medicine). W obrębie pierwszego nurtu badania koncentrowały się na takich czynnikach jak struktury organizacyjne, związki pomiędzy pełnionymi rolami, systemy wartości, rytuały i funkcje medycyny jako systemy zachowań społecznych. Były one prowadzone przez osoby działające na niezależnych stanowiskach, poza formalnym otoczeniem medycznym. Drugi nurt charakteryzował się badaniami lub nauczaniem, które realizowano dzięki współpracy przedstawicieli socjologii i medycyny. Współpraca ta pozwalała integrować różne koncepcje, techniki, ale i samych reprezentantów tych środowisk.

Ten „podwójny” układ odniesienia kształtowany był z jednej strony przez socjologię ogólną z jej metodologia, terminologią i zapleczem teoretycznym, z drugiej zaś przez instytucjonalną medycynę, która "oferuje" szereg problemów badawczych i praktycznych podejmowanych $\mathrm{w}$ badaniach socjomedycznych (Skrzypek 2013: 8).

Socjologia medycyny stała się rodzajem działalności intelektualnej prowadzonej w obrębie medycyny, jak i poza nią. W przestrzeni akademickiej osiągnęła pozycje instytucjonalną niezależną od medycyny, dzięki czemu zyskała podwójną tożsamość - kształtowaną w ramach dyscypliny macierzystej oraz dzięki współpracy z instytucjami medycznymi (Bloom 2002: 24). Z jednej strony postulowano, aby socjologowie dostrzegali i odpowiadali na rosnące znaczenie medycyny we współczesnym świecie, z drugiej, aby nie występowali wobec niej z pozycji podporządkowanych. Realizując te postulaty i podkreślając partnerstwo obu dyscyplin, proponowano rozwój nurtu określanego mianem socjologii z medycyną (sociology with medicine) (Horobin 1985: 105). Orędował za tym również Robert Strauss (1999: 109), który pół wieku po publikacji swojego wpływowego artykułu zauważył, że współcześnie nie ma niczego zaskakującego w tym, iż socjologowie medycyny pełnią rolę badawczą lub dydaktyczną na polu medycyny (in) i jednocześnie studiują jakiś aspekt, który jej dotyczy (of).

Gdy przedstawiciele socjologii medycyny zaczęli coraz chętniej korzystać z dorobku socjologii, utraciła ona swoją podrzędną pozycję względem medycyny, a granice pomiędzy socjologią medycyny i medycyną zaczęły się zacierać (Levine 1987: 5). Można wskazać kilka przyczyn, które zadecydowały o zmianie tego statusu. Po pierwsze, kiedy choroby przewlekłe, a nie choroby o ostrym przebiegu stały się główną przyczyną śmierci we współczesnych społeczeństwach, nastąpił wzrost znaczenia socjologii medycyny dla nauk medycznych. Kluczową rolę zaczęły bowiem odgrywać zachowania społeczne i warunki życia, ważne w procesie zapobiegania, powstawania i przebiegu chorób przewlekłych. Po drugie, w miarę jak socjologia medycyny dojrzewała jako nauka, dostarczała wielu wartościowych opracowań tak dla medycyny klinicznej, jak i polityki zdrowotnej. Po trzecie, sukcesy badawcze wzmocniły status zawodowy socjologów medycyny zarówno w obszarze medycyny, jak i socjologii. Po czwarte, socjologia medycyny ustanowiła własny kierunek badań, który objął praktykę medyczną i politykę jako przedmiot badań. W przypadku zaniedbań czy nadużyć niekompetentnych lekarzy, 
ograniczonego dostępu ludzi biednych do usług medycznych i stawiania interesów zawodowych przed interesem społecznym socjologowie medycyny stali się merytorycznymi krytykami takich praktyk, występującymi z pozycji profesjonalistów (Cockerham 2001: 4) czy wręcz „adwokatów diabła” (Strauss 1999: 109).

Obserwowanym zmianom na polu socjologii medycyny podlega również problematyka niepełnosprawności, która - będąc „zjawiskiem o komponentach medycznych i społecznych - [wymaga - przyp. T.M.] wzrostu zapotrzebowania na wiedzę socjologiczną i kompetencje socjologów" (Ostrowska 2009: 146). Dzięki oparciu się na tej wiedzy obserwujemy obecnie humanizujący zwrot na polu socjologii medycyny. Charakteryzuje się on odejściem od optyki biomedycznej i postawieniem w centrum zainteresowania jednostki konfrontującej się $\mathrm{z}$ problemami choroby i zdrowia. W tym znaczeniu biologiczne ujęcie choroby i chorowania (disease) dopełniane jest o doświadczenia życia z chorobą (illness) (Skrzypek 2013: 10-11).

O ile socjologowie medycyny, dążąc do wyjaśnienia przyczyn chorób lub niepełnosprawności, wiążą elementy medyczne z elementami społecznymi, o tyle reprezentanci disability studies główną wagę przywiązują do identyfikowania i niwelowania barier społecznych i kulturowych. Dla tych pierwszych to choroba (illness) lub niepełnosprawność była społecznym doświadczeniem, konsekwencją upośledzenia funkcji organizmu. Dla drugich niepełnosprawność była skutkiem istniejących nierówności społecznych i społecznej marginalizacji (Shakespeare, Watson 2010: 65).

W tym duchu w studiach nad niepełnosprawnością dominuje tendencja do odrzucania perspektywy mówiącej, że niepełnosprawność jest problemem indywidualnym. Zamiast tego formułuje się założenie, że jest ona konsekwencją społecznej patologii. Zwolennicy tego kierunku przyjmują wręcz za oczywiste, że osoby, którym przypięto etykiety fizycznie, sensorycznie lub poznawczo upośledzonych (impairment), podlegają ideologicznemu i materialnemu wykluczeniu (Goodley 2011: xi).

Studia nad niepełnosprawnością nie rozwijały się w sposób paradygmatyczny, lecz ich początek i rozwój były związane $\mathrm{z}$ ruchami społecznymi inicjowanymi przez reprezentantów środowisk osób niepełnosprawnych w Wielkiej Brytanii i Stanach Zjednoczonych (Barnes, Thomas 2006: 3; Oliver 2006: 7; French, Swain 2008: 19). Jednocześnie w ramach studiów nad niepełnosprawnością Mike Oliver przedstawił nową wykładnię dla rozumienia niepełnosprawności, która zapoczątkowała rozwój „społecznego modelu niepełnosprawności". Jednym z impulsów dla jego rozwoju stały się wytyczne ruchu na rzecz osób niepełnosprawnych - The Union of the Physically Impaired Against Segregation (UPIAS), który odrzucał model niepełnosprawności proponowany przez Światową Organizację Zdrowia (Pfeiffer 2000). W manifeście Podstawowe Zasady Dotyczące Niepełnosprawności (The Fundamental Principles of Disability) opublikowanym w roku 1976 UPIAS definiowała niepełnosprawność (disability) jako „brak lub ograniczenie akty wności, spowodowane taką organizacją społeczeństwa, która nie bierze pod uwage (lub robi to w stopniu niewystarczającym) ludzi niepełnosprawnych fizycznie, a przez to wyklucza ich z udziału w głównym nurcie życia społecznego". Upośledzenie (impairment) oznaczało natomiast „całkowity albo częściowy brak kończyny lub posiadanie wadliwej kończyny, narządu lub funkcji organizmu" (UPIAS 1976: 3-4, 14 [tłum. własne]). 
Bazując na tych wskazówkach, Michael Oliver w swoim ujęciu modelowym dotyczącym niepełnosprawności zwracał uwagę na trzy kwestie. Po pierwsze, niepełnosprawność jest wynikiem oddziaływania barier środowiskowych i kulturowych, a nie jest pochodną ograniczeń funkcjonalnych. Po drugie, niepełnosprawność należy analizować w sposób holistyczny z silnym akcentowaniem jej związku ze środowiskiem społecznym. Po trzecie, interwencje w zakresie ochrony zdrowia, rehabilitacji, edukacji czy zatrudnienia należy przeprowadzać dopiero wówczas, gdy rozpoznane zostaną ograniczenia środowiskowe i opracowane sposoby ich eliminacji (Oliver 1996).

Rozwojowi modelu społecznego towarzyszyło wprowadzenie do debaty naukowej takich pojęć jak ableism czy disablism, których znaczenie nawiązywało do obecnych w języku naukowym terminów „rasizm” czy „seksizm” i współgrało z paradygmatem społecznej opresji (Thomas 2010: 41). Ableizm (forma spolszczona) był „,zbiorem przekonań, procesów i praktyk, które kreują szczególny rodzaj jaźni i cielesności uznany za doskonały, typowy dla gatunku ludzkiego i dlatego też konieczny lub właściwy. Niepełnosprawność oznaczała zatem bycie nie w pełni człowiekiem" (Campbell 2001: 44 [tłum. własne]). Z kolei disablizm (forma spolszczona) był „zbiorem założeń i praktyk promujących odmienne lub nierówne traktowanie osób z powodu rzeczywistych lub domniemanych niepełnosprawności" (Campbell 2009: 21 [tłum. własne]). Oba zjawiska, według zwolenników studiów nad niepełnosprawnością, wpisywały się w szeroki kontekst czynników odpowiedzialnych w przestrzeni społecznej za instytucjonalizację dyskryminacji $\mathrm{z}$ powodu niepełnosprawności. Czynnikami tymi były bariery strukturalne, bariery środowiskowe, $\mathrm{w}$ tym tak zwany disablist lan- guage, oraz bariery w postaci postaw społecznych (Swain, French, Cameron 2003: 2-3).

Odmienne spojrzenie socjologów medycyny i reprezentantów studiów nad niepełnosprawnością na istotę niepełnosprawności, jej przyczyny czy przejawy skutkowało formułowaniem szeregu wzajemnych zarzutów.

Przedstawiciele disability studies wysuwali wobec socjologów medycyny zarzuty, które można streścić w kilku punktach. Po pierwsze, w opinii stronników studiów nad niepełnosprawnością socjologowie medycyny posługują się definicjami niepełnosprawności, które są zasadniczo medykocentryczne, włączając $w$ to te, które zawiera Międzynarodowa Klasyfikacja Funkcjonowania, Niepełnosprawności i Zdrowia. W ten sposób traktują upośledzenie jako przyczynę niepełnosprawności. Po drugie, w badaniach osób przewlekle chorych i niepełnosprawnych koncentrują uwagę na cierpieniu oraz na indywidualnej, psychospołecznej adaptacji do statusu „społecznego dewianta”, do którego sprowadza się życie z niepełnosprawnością. Po trzecie, zbyt rzadko analizują społeczno-strukturalne lub interpersonalne manifestacje i konsekwencje niepełnosprawności. Po czwarte, ignorują przedstawicieli środowisk osób niepełnosprawnych lub sprowadzają ich do roli osób oczekujących współczucia.

Z drugiej strony socjologowie medycyny formułowali pod adresem zwolenników studiów nad niepełnosprawnością zarzuty, które można ująć następująco. Po pierwsze, ci, którzy rozwijają społeczny model niepełnoprawności, nie doceniają dostatecznie wagi upośledzeń. To one prowadzą do rzeczywistej niepełnosprawności poprzez ograniczanie różnych form aktywności i rozbijanie tożsamości 
społecznych osób nią dotkniętych. Po drugie, swoją uwagę koncentrują przede wszystkim na ludziach młodych, ignorując $\mathrm{w}$ ten sposób powszechność chorób przewlekłych wśród osób starszych i powiązaną z nimi niepełnosprawność. Po trzecie, prezentują zbyt przesocjalizowany, redukcjonistyczny i jednowymiarowy obraz niepełnosprawności. Po czwarte, brakuje im teoretycznego wyrafinowania $\mathrm{w}$ analizach problematyki niepełnosprawności (Thomas 2010: 44-45).

Raczej trudno oczekiwać, że reprezentanci obu nurtów osiągną pełny konsensus, który pozwoliłby im wypracować wytyczne dla badań nad problematyką niepełnoprawności. Pewne kroki w tym kierunku zostały poczynione, a ich efekty można obserwować w publikacjach, w których swoje racje przedstawiają rzecznicy obu kierunków badawczych (zob. Albrecht, Seelman, Bury 2001; Scambler, Scambler 2010). Konfrontacje te coraz częściej skutkują rozważaniem racji strony przeciwnej (Thomas 2010), w których głos osób niepełnosprawnych stanowić może kluczowy element w procesie zbliżania obu stanowisk.

\section{Rzecznicy własnej sprawy - niepełnosprawni o sobie}

„Dopuszczenie do głosu” osób, które przez długi czas znajdowały się na pozycjach podporządkowanych w relacjach lekarz-pacjent czy terapeutaosoba niepełnosprawna, wieńczyło długotrwały proces stopniowego odchodzenia od stygmatyzacji, segregacji, dyskryminacji czy medykalizacji. Asymetria wiedzy, statusu i autorytetu przez długi czas pomagała lekarzom kontrolować komunikację z pacjentami i zmuszać ich do funkcjonowania zgodnie $\mathrm{z}$ definicją sytuacji lekarza (Anderson, Helm 1979).
Z czasem dostrzeżono, że laik może mieć swój „nienaukowy" pogląd na chorobę, który zderza się z perspektywą lekarza. Proces leczenia staje się zatem formą negocjacji, a czasami przybiera postać konfliktu (Freidson 1970: 322). Sposób interpretowania własnej choroby (illness) przez pacjenta może być podobny, ale nigdy nie będzie tożsamy z diagnozą medyczną (disease). Jeden głos pochodzi ze świata życia (voice of lifeworld), drugi ze świata medycyny (voice of medicine) (Mishler 1984: 321). I właśnie te głosy osób dotkniętych dysfunkcją wskazywały, że choroba i niepełnosprawność to nie tylko „zakłócenie” występujące na poziomie organizmu, ale również, czy może przede wszystkim, zakłócenie biograficzne (biographical disruption), które burzy sposób organizacji życia codziennego i formy wiedzy, które tej organizacji zapewniały stabilne oparcie (Bury 1982: 169). Cierpienie może prowadzić do utraty własnego ja (loss of self), będącej wynikiem nie tyle bólu fizycznego, co konieczności życia z ograniczeniami, doświadczania społecznej izolacji, dyskredytowania definicji siebie i bycia ciężarem dla innych (Charmaz 1983). W tym sensie choroba czy niepełnosprawność leży u podstaw narracyjnej rekonstrukcji (narrative reconstruction), która jest próbą wyznaczenia istotnych punktów odniesienia dla odzyskania łączności jaźni ze społeczeństwem, utraconej w wyniku choroby czy niepełnosprawności (Williams 1984: 197-198).

Na ile utrata tej łączności (poprzez izolację, wykluczenie, dyskryminację itp.) jest pochodną czynników biologicznych, na ile zaś społecznych pozostaje kwestią sporną. Cennym wkładem, który może przyczynić się do rozwiązania tego sporu, jest bez wątpienia głos laików - osób niepełnosprawnych, które „negocjują” swoją niepełnosprawność zarówno w instytucjach medycznych (w trakcie leczenia czy rehabilitacji), jak i w szerokim społecznym kontekście codziennych aktywności. 
Rozstrzygając ten problem - w jakiej mierze interpretacja własnej niepełnosprawności, jej źródeł i konsekwencji wpisuje się $\mathrm{w}$ nurt socjologii medycyny (dysfunkcja somatyczna jako przyczyna niepełnosprawności), na ile zaś jest wsparciem dla studiów nad niepełnosprawnością (niepełnosprawność jako skutek dysfunkcji społecznej), odwołano się do opinii laików - osób niepełnosprawnych, niezaangażowanych i niezależnych rzeczników „własnej sprawy".

Osoby niepełnoprawne były rekrutowane do badań za pośrednictwem przedstawicieli organizacji lub instytucji (stowarzyszeń, fundacji, domów pomocy społecznej), terapeutów i lekarzy, którzy w swojej pracy mają kontakt z niepełnoprawnymi i jako osoby zaufane mogły zachęcić je do uczestnictwa w badaniach. Spośród osób wyrażających chęć uczestnictwa w badaniach wybrano w sposób celowy 45 z nich. Głównym kryterium wyboru była niepełnosprawność somatyczna o umiarkowanym lub znacznym nasileniu. Drugim kryterium był rodzaj niepełnosprawności. Przy wyborze zadbano, aby próba była pod tym względem jak najbardziej zróżnicowana.

Badania zrealizowano na przełomie roku 2017 i 2018 z wykorzystaniem techniki indywidualnych wywiadów pogłębionych. Z 33 osobami przeprowadzono wywiady bezpośrednie w ich miejscu zamieszkania, pracy lub innym wybranym przez badanego miejscu, natomiast z 11 osobami wywiady telefoniczne. Wszystkie rozmowy nagrywano, poddawano transkrypcji i analizowano za pomocą programu do analizy danych jakościowych QDA Miner'.

\footnotetext{
${ }^{1}$ Więcej na temat organizacji, realizacji oraz wyników badań znaleźć można w: Masłyk 2019.
}

Opierając się na opisie choroby lub schorzenia uczestników badania, wyróżniono kilka rodzajów niepełnosprawności: 1) niepełnosprawność ruchową, 2) choroby układu oddechowego i krążenia, 3) choroby neurologiczne, w tym neurodegeneracyjne, 4) niepełnosprawność narządu wzroku, 5) nowotwory, 6) choroby rzadkie, genetyczne. Uczestnicy badania różnili się również pod względem podstawowych cech socjodemograficznych, takich jak: płeć, wiek (21-94 lata), wykształcenie (podstawowe- wyższe), miejsce zamieszkania (wieś-miasto), stan cywilny. Dodatkowym kryterium, które uwzględniono w analizach, była kategoryzacja doświadczanej przez badanych niepełnosprawności z podziałem na "stan” i „chorobę". Do pierwszej kategorii zakwalifikowano osoby, dla których niepełnosprawność była względnie stabilnym stanem, który nie wpływał determinująco (i negatywnie) na ogólną kondycję fizyczną. W kategorii tej znalazły się osoby niewidome i słabowidzące, osoby po amputacjach i takie, których niepełnosprawność fizyczna zmuszała do korzystania z wózków inwalidzkich. W drugiej kategorii znalazły się osoby, u których niepełnosprawność postępowała wraz z pogłębianiem się choroby bądź też prawdopodobieństwo wystąpienia takiej zależności (z perspektywy medycznej) było wysokie. Kategorię tę reprezentowały osoby z miopatia, zespołem Marfana, fakomatozą (w tym chorobą Recklinghausena), stwardnieniem rozsianym czy stwardnieniem zanikowym bocznym.

Wypowiedzi badanych na temat istoty doświadczanej niepełnosprawności pozwoliły wyróżnić kilka charakterystycznych kategorii interpretacyjnych. Najczęściej niepełnosprawność rozumiano jako naturalny element życia, który został zaakceptowany i nie wymaga doszukiwania się przyczyn, formułowania stosownych wyjaśnień czy wskazywania 
winnych tej sytuacji (31 osób) ${ }^{2}$. Dotyczyło to zazwyczaj tych osób, które były niepełnoprawne od urodzenia. Nie znały życia bez dysfunkcji, a ona sama stawała się uciążliwym, ale w pewnym sensie zwyczajnym elementem ich codzienności. Postawa ta widoczna była w następujących wypowiedziach:

Ja staram się tak myśleć, że jednak to nie jest nic takiego wielkiego, że staram się $\mathrm{w}$ miarę normalnie funkcjonować. Wiadomo, że nie da się wszystkiego tak robić jak osoby pełnosprawne, ale chcę robić jak najwięcej, nie patrzeć się na to. Wiadomo, że nie zawsze wszystko od razu, ale jednak myślę, że jak będę w to wkładała więcej zaangażowania, to nie będę myśleć o tym, że jestem osobą niepełnosprawną. Więc niepełnosprawność determinuje moje wybory, ale jak już ich dokonam, to staram się żyć normalnie, realizować te wybrane cele. Czasami to do mnie wraca, ale staram się o tym nie myśleć. [W43/K/22, niewykształcone kość udowa i kość miednicy $]^{3}$

Nie jestem sobie w stanie wyobrazić innego życia, bo ja się z tym urodziłam. To jest dla mnie codzienność, normalność. Wiadomo, że zdarzają mi się jakieś chwile buntu i tak dalej, dlaczego mnie to spotkało, takie pytania, ale to się zdarza bardzo rzadko, bo ja jestem taka, mam pogodne usposobienie. [W18/K/29, przepuklina rdzeniowa, rozszczep kręgosłupa]

Wśród osób postrzegających swoją niepełnosprawność jako naturalny element życia znalazły się również i takie, które stały się niepełnosprawne na skutek wypadku, w wyniku urazu czy choroby. Go-

\footnotetext{
${ }^{2}$ Opisując istotę swojej niepełnosprawności, uczestnicy badania podkreślali często kilka aspektów i stąd liczba wskaźnikowych wypowiedzi jest większa od liczby uczestników badania.

${ }^{3} \mathrm{~W}$ opisie każdego cytatu znajdują się kolejno: numer wywiadu, płeć, wiek oraz rodzaj niepełnosprawności lub przyczyna, która ją wywołała.
}

dziły się z tym faktem (zazwyczaj po czasie) i przyjmowały, że ich życie na pewno się zmieni, ale nie musi być gorsze od poprzedniego. Przykładem tego podejścia były słowa dwojga rozmówców:

Każdy ma jakiś krzyżyk. Każdy musiał coś dostać albo dostanie. $Z$ niepełnosprawnością trzeba się nauczyć żyć. Z niepełnosprawnością się żyje i trzeba ją przede wszystkim zaakceptować. Znam ludzi, którzy nie akceptują własnej niepełnosprawności, z nimi się nie da rozmawiać o ich niepełnosprawności, bo to jest dla nich bardzo trudny temat, a dopóki się niepełnosprawności nie zaakceptuje... ja nie traktuję tego, że nie widzę, że to jest jakaś krzywda. Ja dwadzieścia pięć lat temu, jak się śmieję, przeszedłem na ciemną stronę mocy i tyle. To jest zupełnie co innego, to jest inne życie. Kiedyś widziałem, wiem, jak wygląda niebo, jak wyglądają kolory, potrafię sobie to wyobrazić. [W29/M/40, ociemniały] 4

Jakoś tak nie byłam po tym wypadku załamana, bo tam sobie życie odbierają niektórzy, a ja myślałam, że coś będzie innego w moim życiu. Teraz sobie tak rozmyślam, co by było, gdyby nie było tego wypadku. Nie wiem, czy bym miała męża, czy bym miała dzieci i dom. Przez wypadek to też poznałam dużo ludzi, zwiedziłam dużo miejscowości, bo to obozy były różne dla niepełnosprawnych, czy sanatoria, czy turnusy rehabilitacyjne. Przed ciążą to jeszcze udzielałam się sportowo na wózku. Siatka, szermierka, takie rzeczy. [W17/K/50, paraplegia]

Drugim, najczęstszym sposobem interpretacji niepełnosprawności było utożsamianie jej z chorobą

\footnotetext{
${ }^{4}$ Uczestników badania z problemami wzroku zaklasyfikowano do trzech kategorii: osób słabowidzących (tracących wzrok w przebiegu różnych schorzeń), ociemniałych (które utraciły wzrok w wyniku wypadków i schorzeń po 5. roku życia) i niewidomych (które urodziły się niewidome lub straciły wzrok przed ukończeniem 5. roku życia) (zob. PZN 2015).
} 
(22 osoby). Badani bardzo dokładnie opisywali istotę choroby, jej objawy, skutki, podjęte terapie i sposoby leczenia. Choroba towarzyszyła im na co dzień i codziennie mierzyli się z jej konsekwencjami. Stosunek taki można odnaleźć w poniższych wypowiedziach:

Moja przypadłość to neurofibromatoza, która jest bardzo rzadką chorobą i o której wiele lat się nie mówiło i wielu lekarzy nawet nie wiedziało, co to jest za choroba. Naprawdę jest już bardzo duży postęp, jeśli chodzi o tę chorobę [...]. Ja oprócz tego jestem też po dwóch nowotworach i po bardzo rozległym zawale serca. Główną moją niepełnosprawnością jest ta choroba Recklinghausena, czyli NF1. Ta choroba z racji tego, że jestem jeszcze obciążona mutacją genu TP53, jest to gen, który odpowiada za choroby nowotworowe, ta choroba wydaje mi się, że w moim wieku przyspieszyła te choroby wszystkie, takie upośledzające funkcjonowanie. Na pewno ta choroba ma wpływ na to, że te bóle nowotworowe są silniejsze i ciężej się to przechodzi. [W44/K/46, choroba Recklinghausena i choroba nowotworowa]

Dla mnie to jest po prostu zwykła jak gdyby choroba. Podchodzę do tego, jak podchodzi medycyna, na ileś tam tysięcy urodzeń występuje mutacja genu FBN1, który koduje fibrylinę. Ale to wynika po prostu z takiej pewnej epidemiologii, że występowanie tego $\mathrm{w}$ populacji tak... tak występuje. Nie traktuję tego ani jako zrządzenia losu czy też... nie tłumaczę tego w inny sposób niż to, że po prostu tak się dzieje. I póki co nie wiemy, skąd się bierze taka mutacja, to znaczy medycyna nie wie, skąd się bierze taka mutacja. I tyle, to mi wystarcza i nie potrzebuję innych wytłumaczeń. [W7/M/31, zespół Marfana]

Trzecim sposobem interpretacji istoty niepełnosprawności było powoływanie się na siły transcen- dentne, działanie opatrzności czy przeznaczenia (19 osób). Wskazywano tutaj boską ingerencję (często postrzegając ja przez pryzmat pokuty), powoływano się na los i nieuchronność jego wyroków. W tym kontekście niepełnosprawność utożsamiano niekiedy ze swoistym darem. Ten trojaki, opatrznościowy sposób myślenia o swojej niepełnosprawności można dostrzec w następujących słowach:

Tak, ja myślę, że to jest dopust boży. Mam sobie sama radzić w milczeniu, nie skarżyć się, bo to jest moja pokuta życiowa. Niepełnosprawność to wielka uciążliwość, ale może też droga do uświęcenia. [W13/K/66, słoniowacizna]

Myślę, że tak miało być. Tak było zapisane, że mi się tak stanie. Miałam pecha. Najpierw, jak siedem lat miałam, to złamałam sobie nogę. Później, jak miałam szesnaście, to złamałam sobie rękę. W wieku dziewiętnastu złamałam kręgosłup. I tak sobie to tłumaczę. Nie wiem, jakoś nie byłam załamana $\mathrm{z}$ tego powodu, że miałam wypadek. [W17/K/50, paraplegia]

I mi się wydaje, że dla mnie to nie jest przekleństwo. Wydaje mi się, że to jest taki trochę dar. Bo mnie więcej to nauczyło niż... ja nie wiem, czy by mi nie odbiło i nie siedziałabym w korporacjach i nie wiadomo co, gdybym była zupełnie zdrowa i mogłabym sobie pozwolić na różne tam rzeczy, pracę i tak dalej. Nie wiem, czy by mi nie odwaliło, czy nie byłabym wredną taką suką, za przeproszeniem. [W20/K/50, słabowidząca]

Czwarty sposób „oswajania” niepełnosprawności był związany z winą (10 osób) - niekiedy własną, niekiedy innych. $W$ tym pierwszym przypadku winy doszukiwano się w sobie, obarczano się konsekwencjami własnej nierozwagi, głupoty, braku ostrożności. W drugim przypadku wskazywano 
bezpośrednich sprawców swojej sytuacji. Oba te stanowiska oddają wypowiedzi dwóch rozmówców:

Zdaję sobie sprawę z tego, że sam sobie na to zapracowałem, swoim trybem życia, higieną życia, dietą, pracą, stylem życia. [...] Ale decydującą rolę odgrywał stres. [W19/M/58, miażdżyca tętnic, stan po amputacji nóg]

Tu nie ma co wiele wyjaśniać. Uderzył mnie samochód przy prędkości dziewięćdziesiąt kilometrów na godzinę. Miałem ucisk na rdzeń kręgowy, byłem w śpiączce ponad trzy tygodnie i to jest taki okres, po którym ten rdzeń się już nie regeneruje. Do ośmiu godzin, gdybym miał to obciążenie zdjęte $\mathrm{z}$ tego kręgosłupa, to może ruszałbym nogami. [W36/M/36, paraplegia]

Stosunkowo niewielu uczestników badania (6 osób) wskazywało, że ich niepełnosprawność „pogłębia się" (szczególnie w wymiarze doznać psychicznych) na skutek postaw, jakie inni ludzie przyjmują w stosunku do nich. Charakteryzują się one zarówno dystansem opartym na niechęci, ale również nieadekwatnym współczuciem czy wręcz litowaniem się nad „niedolą” osób niepełnosprawnych. Te kwestie uwypuklone zostały w następujących słowach:

Ale jest też w tym efekt tego, jak traktują mnie inni. Bo już te plamy i guzki wystarczą, żeby gapili się jak na odmieńca. Te dwa punkty łączę ze sobą, to znaczy przypadkowość i podejście innych. Potrzebuję wsparcia, a go nie mam. Dlatego ten efekt jest dla mnie tak wyraźny i bolesny. Gdybym miał to wsparcie, moja niepełnosprawność schodziłaby na dalszy plan. Gdybym był bardziej akceptowany, zmotywowany, miałbym może mniejszy brak wiary w siebie. Nie jestem gąbką, którą można wypłukać i wycisnąć. Ja nasią- kam i zostaje to we mnie. Choćby wstyd mojego ojca, że ma niewydarzonego syna. [W33/M/39, choroba Recklinghausena]

Mi się wydaje, że sama niepełnosprawność to jest większy problem osób pełnosprawnych, które na nas patrzą gdzieś tam z zewnątrz. Czy to jest osoba na wózku, czy osoba niewidoma - oj biedny, oj biedna. [W8/M/25, słabowidzący]

Chociaż osoby badane różniły się podejściem do swojej niepełnosprawności, a różne sposoby rozumienia jej istoty współwystępowały w poszczególnych wypowiedziach, to jednak wyraźny podział zarysował się pomiędzy osobami ze "stabilną" dysfunkcją oraz osobami chorymi. Gdyby sparafrazować wypowiedzi wszystkich uczestników badania i ująć je w jednej, uniwersalnej metaforze to $\mathrm{w}$ przypadku osób z tej pierwszej kategorii niepełnosprawność należałoby rozumieć jako „walkę z ograniczeniami” (najczęściej swoimi własnymi), natomiast w przypadku tych drugich - jako „walke $\mathrm{z}$ chorobą". Te różnice zarysowały się w postawie dwojga uczestników badania:

To jest trudne, to jest trudne, jak to innym wytłumaczyć. Jest to na pewno dużym utrudnieniem $\mathrm{w}$ życiu. Jest to na pewno zmiana planów życiowych. Jest to zmiana jakichś tam wartości, ale jest to też pewnego rodzaju wyzwanie, bo od wielu, wielu lat już wychodzę z takiego założenia, że przeszkody są po to, aby je pokonywać, a nie po to, żeby przed nimi siadać. Bo jak się poddajemy przy byle trudności, to nie ruszymy z miejsca, to nic nie jesteśmy w stanie zrobić, działać. Jak się pokonuje te przeszkody, to do czegoś tam można dojść. Między innymi jest to jakiś sens życia, żeby iść do przodu, a nie poddawać się czy załamywać przy jakimś tam problemie. [W31/M/59, ociemniały] 
Niepełnosprawność... ale ja nie będę mówiła ogólnie, ale będę mówiła o moim SM, to bomba zegarowa. Cały czas tyka, ale ja nie wiem, kiedy wybuchnie. I tak bym to opowiedziała, zobrazowała. Na razie, dzięki Bogu, mimo ograniczeń, jestem zdolna do samodzielności. Ale wystarczy kolejny rzut i nie wiem, czy podniosę się z łóżka, czy zachowam mowę, wzrok, po prostu tego nie wiem. [W39/K/54, stwardnienie rozsiane]

Te jakościowe różnice w stanowiskach poszczególnych uczestników badania dostrzec można również w ujęciu ilościowym - zestawieniu prezentującym liczbę wypowiedzi wskaźnikowych przedstawicieli jednej i drugiej kategorii. Osoby z „dysfunkcją" istotnie częściej traktowały swoją niepełnosprawność jako naturalny stan i akceptowały go, natomiast osoby chore swoją niepełnosprawność charakteryzowały zazwyczaj jako problem zdrowotny. W przypadku pozostałych interpretacji nie wystąpiła istotna różnica pomiędzy tymi dwiema porównywanymi kategoriami rozmówców (tabela 1).

\section{Tabela 1. Liczba wypowiedzi wskaźnikowych na temat natury niepełnosprawności u osób z dysfunkcją i osób chorych.}

\begin{tabular}{|l|c|c|c|}
\hline $\begin{array}{c}\text { Rozumienie przyczyny } \\
\text { niepełnosprawności }\end{array}$ & $\begin{array}{c}\text { Natura } \\
\text { niepełnosprawności }\end{array}$ & Test F \\
\hline choroba & dysfunkcja & \\
\hline naturalny stan/akceptacja & $16,1 \%$ & $50,5 \%$ & $16,7^{*}$ \\
\hline problem zdrowotny/choroba & $45,2 \%$ & $18,9 \%$ & 10,3 \\
\hline ingerencja sił wyższych/Boga & $12,8 \%$ & $5,3 \%$ & 2,54 \\
\hline zrządzenie losu & $9,7 \%$ & $9,5 \%$ & 0,06 \\
\hline dar & $6,5 \%$ & $2,1 \%$ & 1,24 \\
\hline wina własna & $0,0 \%$ & $4,2 \%$ & 0,79 \\
\hline skutek działania innych ludzi & $3,2 \%$ & $5,3 \%$ & 0,09 \\
\hline stosunek innych ludzi & $6,5 \%$ & $4,2 \%$ & 0,48 \\
\hline
\end{tabular}

*Uwaga: różnica istotna statystycznie dla p <0,05.

Źródło: opracowanie własne.
Co warte podkreślenia, zarówno w pierwszym, jak i drugim przypadku konsekwencji ograniczeń czy dolegliwości chorobowych poszukiwano najczęściej w sobie, wiązano je z niepełnosprawnością w sposób immanentny. Niezależnie od tego, jak interpretowano swoją niepełnosprawność i jej przyczyny, kształtowała ona sposób życia i wpływała na jego jakość. Wokół doświadczanej dysfunkcji budowany był status centralny danej osoby. Badani zaznaczali, że o niepełnosprawności nie można zapomnieć, zbagatelizować jej, nie uwzględniać w procesie definiowania i realizacji życiowych celów. Ponadto nie sposób wyobrazić sobie świata (jakkolwiek utopijny ten świat miałby być), w którym nie wywierałaby ona wpływu na przebieg tego procesu.

Co więcej, rozmówcy w przeważającej większości mówili o możliwości „,wyjścia z niepełnosprawności" jedynie pod warunkiem powrotu do normalności (sprawności lub zdrowia). Odwoływanie się do normalności, wyobrażonej - w przypadku osób niepełnosprawnych od urodzenia, bądź też doświadczanej - u osób, które zachorowały lub uległy wypadkowi, stanowiło charakterystyczny punkt odniesienia. Punkt ten, umiejscowiony na osi życia danej osoby, wyznaczał alternatywne ścieżki: tę aktualną i tę potencjalną.

W tej perspektywie osoby niepełnosprawne od urodzenia konfrontowały życie własne z życiem sprawnych rówieśników, którzy stanowili dla tych pierwszych swoistą kategorię odniesienia, wyznaczając pewne normy (większą samodzielność, relatywną łatwość wyboru ścieżki zawodowej i edukacyjnej, większe szanse na budowanie związków emocjonalnych, możliwość realizowania zainteresowań itp.). Osoby, które stały się niepełnosprawne na skutek wypadku, urazu czy choroby, porównywały swoje życie "sprzed” z życiem "po", dokonując za- 
zwyczaj negatywnego bilansu. Z kolei osoby chore przewlekle wracały do czasów sprzed choroby lub też do czasu sprzed kolejnego epizodu pogarszającego stan zdrowia (np. osoby ze stwardnieniem rozsianym, stwardnieniem bocznym zanikowym czy miopatią). Charakter tych trzech punktów odniesienia obrazują wypowiedzi trojga uczestników badania:

Wkurza mnie to nieraz, muszę się tłuc tym autobusem nieraz godzinę, a samochodem można byłoby zajechać $\mathrm{w}$ dwadzieścia minut. Jest godzina dziewiętnasta-dwudziesta, bierzesz samochód, jedziesz do galerii, robisz zakupy i jest święty spokój. A tak to kosztuje to trochę więcej zdrowia, więc są jakieś tam momenty, które na pewno ograniczają, bo to też nie mówię o tym, że to się żyje w stu procentach tak samo jak inni. Dzisiaj szukałem dwadzieścia minut kluczy do pracy, zanim wyszedłem z mieszkania, a okazało się, że leżały na samym skraju blatu, a ja tam ręką nie sięgnąłem. [W26/M/27, niewidomy]

Ja bym sobie nie życzyła, aby mieć jakąś dolegliwość i chciałabym być zdrowa i sprawna. Pomimo tych moich lat to wolałabym być sprawna i żebym sobie dawała radę sama ze sobą, żebym nie potrzebowała takiej całkowitej opieki. Ten brak nogi wyznaczył mój tryb życia i on teraz ogranicza najbardziej. [W4/K/94, stan po amputacji nogi]

Dalsze rzuty, to po każdym już wychodziłam z jakimś uszczerbkiem. Już zostało mi zwiotczenie, nie utrzymam się teraz na nogach za długo. Mam osłabiony wzrok, niedosłuch i boję się każdego następnego rzutu, że stanę się całkiem niesprawna, a przecież do tego ta choroba zmierza. Siada się na wózku inwalidzkim, zaczynają się problemy z oddychaniem, połykaniem, mówieniem, nie można ruszyć ręką ani nogą. I człowiek staje się roślinką. Wiem, że jak dłu- żej pożyję, to mnie to czeka. [W37/K/56, stwardnienie boczne zanikowe]

Truizmem jest spostrzeżenie, że każdy swoją niepełnosprawność traktuje inaczej, gdyż jest elementem wplecionym w szeroki kontekst doświadczeń osobistych i relacji społecznych. Jednakże na podstawie wypowiedzi uczestników badania i w odwołaniu do argumentacji przedstawianej przez socjologów medycyny i zwolenników studiów nad niepełnosprawnością można sformułować kilka ważnych, ogólnych konkluzji. Po pierwsze, niepełnosprawność interpretowana była przede wszystkim $\mathrm{w}$ perspektywie indywidualnej $\mathrm{z}$ mocnym zaakcentowaniem wagi elementów medycznych (diagnozy, interwencji, rehabilitacji czy leczenia). Po drugie, rozumienie istoty niepełnosprawności przez osoby nią dotknięte wpisywało się w szeroki kontekst zróżnicowanych interpretacji, z których każda wydaje się pełnić swoistą i ważną rolę w „oswajaniu” swojej dysfunkcji. Po trzecie, w podejściu do swojej niepełnosprawności zarysowała się wyraźna różnica pomiędzy osobami, dla których niepełnosprawność jest relatywnie stabilnym stanem, i tymi, którzy uważają się za osoby chore. W tym drugim przypadku perspektywa medyczna była determinująca. Po czwarte, wypowiedzi badanych osób w sposób nieintencjonalny potwierdzały istnienie takich zjawisk jak disablism czy ableism, poprzez wyraźne odwoływanie się do świata „norm” właściwych dla osób sprawnych (innych lub siebie sprzed niepełnosprawności). Nie była to jednak dychotomia o wydźwięku pejoratywnym, w której osoby niepełnosprawne stawiałyby się po stronie tych marginalizowanych czy dyskryminowanych. Tworzyła ona raczej specyficzny układ odniesienia dla interpretacji własnej dysfunkcji. 


\section{Podsumowanie}

Gdyby wypowiedzi uczestników badania potraktować jako głos w sporze pomiędzy socjologami medycyny i reprezentantami studiów nad niepełnosprawnością, to dałyby one silniejsze wsparcie dla argumentacji przedstawianej przez tych pierwszych. Niepełnosprawność interpretowana była przede wszystkim w ujęciu indywidualnym, a opowiedziane historie wpisywały się w liniowy układ: etiologia, patologia i manifestacja. W większości przypadków niepełnosprawność „pojawiała się" w momencie zaistnienia dysfunkcji i była z nią nierozerwalnie związana. Szczególnie mocno ta zależność akcentowana była przez osoby przewlekle chore, dla których przebieg życia warunkowany był nieuchronnym i koniecznym uczestnictwem w konsultacjach, terapiach czy interwencjach medycznych. Założenia modelu społecznego, który silniej podkreśla wagę barier zewnętrznych $\mathrm{w}$ kształtowaniu niepełnosprawności, rzadziej znajdowały potwierdzenie w rozmowach z uczestnikami badania lub miały znaczenie drugorzędne. Dla badanych wychodzenie z niepełnosprawności nie oznaczało niwelowania barier infrastrukturalnych czy społecznych, ale praktycznie najczęściej i najmocniej wiązano je z powrotem do zdrowia lub „pełnej sprawności”. Ten punkt widzenia pokazuje, że w opinii badanych niepełnoprawność była w sposób immanentny powiązana $\mathrm{z}$ upośledzeniem.

Uczestnicy badania zwracali uwagę, że niepełnosprawność ma naturę wykluczającą na różnych płaszczyznach, ale również i tutaj akcentowana była częściej waga własnych niemożności niż wpływ czynników zewnętrznych. Innymi słowy, badani relatywnie rzadko opisywali siebie jako osoby wykluczone czy dyskryminowane z powodu postaw społecznych, istniejących wzorów instytucjonalnych czy rozwiązań infrastrukturalnych.

Można tutaj odwołać się do danych ilościowych pochodzących z Europejskiego Sondażu Społecznego (ESS Round 9 2018), które są potwierdzeniem tej relatywnie niewielkiej skali doświadczanej dyskryminacji. Pokazują one, że wśród osób niepełnosprawnych w Polsce jest stosunkowo niewielki odsetek tych, którzy doświadczają dyskryminacji. W badaniu sondażowym osoby niepełnosprawne wyróżniono na podstawie pytania o niepełnosprawność biologiczną: „czy w wykonywaniu codziennych czynności napotyka P. jakieś utrudnienia wynikające $\mathrm{z}$ długotrwałej choroby, niepełnosprawności, jakichś dolegliwości czy też problemów natury psychicznej?". Na pytanie to można było udzielić odpowiedzi "tak, w dużym stopniu", „tak, do pewnego stopnia” i „nie”. Przynależność do grupy dyskryminowanej (pytanie: czy uznałby/-aby się P. za osobę należącą do grupy ludzi, która jest dyskryminowana, gorzej traktowana niż inne grupy w kraju?") zaznaczyło 10,6\% osób ze znaczną niepełnosprawnością i 6\% z niepełnosprawnością umiarkowaną. Adekwatnie, 9,4\% wśród osób z pierwszej kategorii i $1 \%$ z drugiej przyznało, że czuje się dyskryminowana ze względu na niepełnosprawność.

Oczywiście ten relatywnie niewielki odsetek nie powinien usprawiedliwiać braku działań ukierunkowanych na poprawę sytuacji osób niepełnosprawnych. Wskazuje jednak, że akcenty w sposobie interpretowania niepełnosprawności i jej przyczyn należy rozłożyć proporcjonalnie. Właściwym rozwiązaniem, które należałoby w tym celu

\footnotetext{
5 Takie szerokie, biologiczne kryterium niepełnosprawności (Are you hampered in your daily activities by a chronic physical or mental health problem, illness, or disability?) wykorzystywane jest m.in. w badaniach Eurostatu realizowanych w krajach Unii Europejskiej (zob. European Communities 2001).
} 
promować, jest zbliżenie stanowisk reprezentowanych przez socjologów medycyny i studiów nad niepełnosprawnością.

Jak zaznaczono wyżej, takie inicjatywy są już podejmowane. Ich pożądany kierunek wskazują między innymi Tom Shakespeare i Nick Watson (2010: 72-74). Według nich badania dotyczące niepełnosprawności powinny pokazywać to, co myślą i mówią osoby niepełnoprawne, a nie to, co zakładamy, że powinny myśleć i mówić. Co więcej, chociaż istotne jest gromadzenie i interpretacja danych na temat barier, uprzedzeń czy ucisku, to jednak nie można pomijać istotnych dla niepełnosprawności

\section{Bibliografia}

Albrecht L. Gary (2010) The Sociology of Disability: Historical Foundations and Future Directions [w:] Chloe E. Bird et al., eds., Handbook of Medical Sociology. Sixth Edition. Nashville: Vanderbilt University Press, s. 192-209.

Albrecht L. Gary, Seelman Katherine D., Bury Michael (2001) Introduction: The Formation of Disability Studies [w:] Gary L. Albrecht, Katherine D. Seelman, Michael Bury, eds., Handbook of Disability Studies. Thousand Oaks, London, New Delhi: Sage Publications, s. 1-8.

Anderson Timothy W., Helm David T. (1979) The Physician-Patient Encounter: A Process of Reality Negotiation [w:] Jaco E. Gartly, ed., In Patients, Physicians, and Illness, New York: Free Press, s. 259-271.

Barnes Colin, Thomas Carol (2006) Introduction [w:] Len Barton, ed., Overcoming Disabling Barriers. 18 years of Disability and Society. London, New York: Routledge, s. 3-6.

Bloom Samuel W. (2002) The Word as Scalpel. A History of Medical Sociology. New York: Oxford University Press. aspektów oddziałujących na poziomie indywidualnym (medycznej klasyfikacji poszczególnych rodzajów niepełnosprawności, doświadczeń psychospołecznych kształtujących różnice osobowościowe, kulturowych skutków etykietowania niepełnosprawności itp.). Ponadto należy uznać, że osoby niepełnosprawne definiują swoją niepełnosprawność na własnych warunkach, będąc jedną ze stron dyskusji. Ich koncepcja tożsamości jest konstruktem dynamicznym, kształtowanym w sposób kreatywny i refleksyjny. Aby te cele osiągnąć, należy uwzględnić wagę „mediujących” opinii osób niepełnosprawnych. Opinii laików, ale przede wszystkim rzeczników własnej sprawy.

Bury Michael (1982) Chronic illness as biographical disruption. "Sociology of Health and Illness", vol. 2, s. 167-182.

Campbell Kumari Fiona (2001) Inciting legal fictions: Disability's date with ontology and the ableist body of the law. "Griffith Law Review", vol. 10, s. 42-62.

Campbell Kumari Fiona (2009) Disability Harms: Exploring Internalized Ableism [w:] Catherine A. Marshall et al. , eds., Disabilities. Insights from across Fields and around the World. Westport: Praeger Publishers, s. 19-33.

Charmaz Kathy (1983) Loss of self: a fundamental form of suffering in the chronically ill. „Sociology of Health and Illness", vol. 2, s. 168-195.

Cockerham William C. (2001) Medical Sociology and Sociological Theory [w:] William C. Cockerham, ed., The Blackwell Companion to Medical Sociology. Malden, Oxford: Blackwell Publishers, s. 3-22.

Cockerham William C. (2016) Medical Sociology. Thirteenth Edition. London, New York: Routledge. 
Conrad Peter, Schneider Joseph W. (1992) Deviance and Medicalization. From Badness to Sickness. Philadelphia: Temple University Press.

ESS Round 9: European Social Survey Round 9 Data (2018) Data file edition 1.1. NSD - Norwegian Centre for Research Data, Norway - Data Archive and distributor of ESS data for ESS ERIC.

European Communities (2001) Disability and social participation in Europe. Luxembourg: Office for Official Publications of the European Communities.

Freidson Eliot (1970) Profession of Medicine. A Study of the Sociology of Applied Knowledge. New York: Dodd, Mead \& Company.

French Sally, Swain John (2008) There but for Fortune [w:] John Swain, Sally French, eds., Disability on Equal Terms. Los Angeles, London, New Delhi, Singapore: Sage Publications, s. 7-20.

Gabe Jonathan, Bury Mike, Elston Mary Enn (2004) Key Concepts in Medical Sociology. London, Thousand Oaks, New Delhi: Sage Publications.

Goodley Dan (2011) Disability Studies. An Interdisciplinary Introduction. New Delhi; Sage Publications.

Haveman Meindert (2006) Aging, International [w:] Gary. L. Albrecht, ed. Encyclopedia of Disability. Volume I. Thousand Oaks: Sage Publications, s. 78-84.

Horobin Gordon (1985) Review Essay: Medical sociology in Britain: true confessions of an empiricist. "Sociology of Health and Illness", vol. 1, s. 94-107.

ICIDH (1980) International Classification of Impairments, Disabilities, and Handicaps. Geneva: World Health Organization.

ICIDH-2 (2001) International Classification of Functioning Disabilities, and Health. Geneva: World Health Organization.

Levine Sol (1987) The Changing Terrains in Medical Sociology: Emergent Concern with Quality of Life. "Journal of Health and Social Behavior", vol. 1, s. 1-6.

Masłyk Tomasz (2019) Po pierwsze człowiek. Kapitał społeczny osób niepetnosprawnych w Polsce. Warszawa: Wydawnictwo Naukowe Scholar.

Mishler Elliot G. (1984) The Discourse of Medicine: Dialectics of Medical Interviews. Norwood, NJ: Ablex.
Nagi, Saad Z. (1965) Some conceptual issues in disability and rehabilitation [w:] Marvin B. Sussman, ed., Sociology and rehabilitation. Washington, DC: American Sociological Association, s. $100-113$.

Oliver Michael (1996) DefiningImpairment and Disability, Issues at Stake [w:] Colin Barnes, Geof Mercer, eds., Exploring the Divide. Illness and Disability. Leeds: Leeds University Press, s. 29-54.

Oliver Michael (2006) If I had a hammer: the social model in action [w:] John Swain et al., eds., Disabling Barriers - Enabling Environments. London: Sage Publications, s. 7-12.

Ostrowska Antonina (2009) Niepetnosprawność, rehabilitacja i integracja społeczna osób niepetnosprawnych [w:] Antonina Ostrowska, red., Socjologia medycyny. Podejmowane problemy, kategorie analizy. Warszawa: Wydawnictwo IFiS PAN, s. 146-171.

Pfeiffer David (2000) The devils are in the details: the ICIDH2 and the disability movement. „Disability and Society”, vol. 7, s. 1079-1082.

PZN (2015) Niewidomy, stabowidzacy, ociemniaty, tracacy wzrok. Definicje, różnice. Polski Związek Niewidomych [dostęp 14 kwietnia 2018 r.]. Dostępny w Internecie: 〈http://pzn. org.pl/niewidomy-ociemnialy-slabowidzacy-tracacy-wzrokdefinicje-roznice».

Scambler Graham, Scambler Sasha, eds., (2010) New Directions in the Sociology of Chronic and Disabling Conditions Assaults on the Lifeworld. New York: Palgrave Macmillan.

Shakespeare Tom, Watson Nick (2010) Beyond Models: Understanding the Complexity of Disabled People's Lives [w:] Graham Scambler, Sasha Scambler, eds., New Directions in the Sociology of Chronic and Disabling Conditions Assaults on the Lifeworld. Basingstoke, New York: Palgrave Macmillan, s. 57-76.

Skrzypek Michał (2013) Wstęp [w:] Michał Skrzypek, red., Socjologia medycyny w multidyscyplinarnych badaniach humanizujacych biomedycyne. Lublin: Wydawnictwo KUL, s. 5-29.

Snyder Sharon L. (2006) Disability Studies [w:] Gary L. Albrecht, ed., Encyclopedia of Disability. Volume I. Thousand Oaks: Sage Publications, s. 478 -490 .

Sokołowska Magdalena (2009) Socjologia medycyny [w:] Antonina Ostrowska, red., Socjologia medycyny. Podejmowane problemy, kategorie analizy. Warszawa: Wydawnictwo IFiS PAN, s. 21-39.

Strauss Robert (1957) The Nature and Status of Medical Sociology. "American Sociological Review", vol. 2, s. 200-204. 
Strauss Robert (1999) Medical Sociology: A Personal Fifty Year Perspective. "Journal of Health and Social Behavior", vol. 2, s. $103-110$.

Swain John, French Sally, Cameron Colin (2003) Controversial Issues in a Disabling Society. Berkshire: Open University Press.

Thomas Carol (2010) Medical Sociology and Disability Theory [w:] Graham Scambler, Sasha Scambler, eds., New Directions in the
Sociology of Chronic and Disabling Conditions Assaults on the Lifeworld. New York: Palgrave Macmillan, s. 37-56.

UPIAS (1976) Fundamental Principles of Disability. London: Union of the Physically Impaired Against Segregation.

Williams Gareth (1984) The genesis of chronic illness: narrative re-construction. "Sociology of Health and Illness", vol. 2, s. $175-200$.

\title{
Cytowanie
}

Masłyk Tomasz (2020) Laicy jako rzecznicy. Opinie osób niepetnosprawnych jako głos w polemice toczonej przez reprezentantów socjologii medycyny i studiów nad niepetnosprawnościa. „Przegląd Socjologii Jakościowej”, t. 16, nr 3, s. 84-100 [dostęp dzień, miesiąc, rok]. Dostępny w Internecie: 〈www.przegladsocjologiijakosciowej.org〉. DOI: http://dx.doi.org/10.18778/1733-8069.16.3.06

\section{Laymen as Advocates: Opinions of People with Disabilities as a Polemical Voice in the Discussion Held by Representatives of Medical Sociology and Disability Studies}

\begin{abstract}
In the second half of the twentieth century, the thematic area of disability became the subject of academic debates and empirical research conducted in the field of social sciences within two simultaneously developing currents. Within the first one, i.e. medical sociology, attention was directed to the nature and causes of chronic diseases and disabilities, focusing on broadly understood health dysfunctions, interpreted most often on an individual basis. Within the second one, namely disability studies, the researchers' attention was focused primarily on social problems as a source of disability (the social model) and on adequate remedies. In the social model, disability was treated as a derivative of broadly defined external constrains, and not as a consequence of bodily dysfunction.

The aim of this article is to present the theoretical assumptions behind these two currents while taking into account the opinion of people with disabilities as a polemical voice in the ongoing discussion. Opinions on the nature of their own disability, its sources, and consequences were expressed by forty-five people with disabilities, who took part in the field research carried out using the technique of individual in-depth interviews. The participants generally interpreted their disability and its causes in a medical (individualistic) perspective. They treated the dysfunction itself as fundamental for building the central status, negating or ignoring the basic premises of the social model.
\end{abstract}

Keywords: medical sociology, disability studies, disability, qualitative research 